\title{
Security and Treatment of Protected Witness Prisoners
}

\author{
Resmi Hoxha \\ PhD Candidate at Tirana European University, Albania. \\ Email: resmi.hoxha@live.com
}

\section{Doi:10.5901/ajis.2013.v2n8p531}

\begin{abstract}
The protected witness prisoners are a specific category which requires adequate institutional training in accordance to the international standards while always having in central of attention their protection and safety. The protected witness prisoners as a specific category of prisoners, their safety is always endangered by different factors due to the fact that they are witnesses of an event, which is an aggravated criminal act with exceptional interest to the justice institutions for adequate decision making.Correctional Service of the Republic of Kosovo in accordance to the legal infrastructure has established necessary institutions for the protection, safety and training of the prisoners in all categories, such as: detained persons, prisoners by court verdict, high risk prisoners, juveniles and the witness protection prisoners as an specific category. For the institutional treatment of this specific category of the prisoners, the Kosovo Correctional Service in cooperation with the international factor in Kosovo has proved since two years ago that is competent to deal with adequate treatments of this specific category of prisoners and their safety by fulfilling international criteria's and standards as well those originating from laws in power.
\end{abstract}

Keywords. Witness protection prisoner, Safety, Treatment, International Standards and Legal infrastructure.

\section{Development aspect of the correction service institutions in Kosovo since 1999}

The initiation of the air strikes by NATO, (Clinton, 2004) in Kosovo, triggered the arrest of large number of the citizen in the streets, without any court verdict. The same were placed into correctional institutions. They went through inhumane treatment and the witnesses speak that they suffered physical and psychological tortures and that they had only one meal per day only to survive. Some of these people were not able to face this situation and committed suicide. They openly requested to be executed by the regime institutions rather to be ill-treated in such inhumane manner.

The end of the war in Kosovo found the correctional institutions damaged in the aspect of infrastructure. In this aspect it is important to note that the history of the penitentiary system is an integral part of the overall history of one country, as such the Institutions of Kosovo do not make any exception (Sadiku, 2010). Initially, after the entry of KFOR (Halbauer, 2012) forces in Kosovo, all institutions, such as: Detention Centers and Correction Centers were under administration and management of KFOR, for the period June - November 1999.

\section{Security and treatment of the prisoners during International Administration by UNMIK on $1999-2008$}

Correctional Institutions in Kosovo have started to be operational by the end of the year 1999 by UNMIK ${ }^{1}$, within Pillar I for Justice and as a reserved responsibility of the SRSG ${ }^{2}$ and supported by the local staff the Detention Center in Prizren started its operation in November 1999.

After the war, the inherited situation of the non functional correctional institutions with damaged building infrastructure. Nevertheless, these institutions have been consolidated and became operational to hold the detained persons as well the prisoners through the assistance from international community. Since the beginning of 1999, many positive changes and visible developments were done in building infrastructure and in promotion of the work quality. The establishment of the Detention Center in Prizren was followed by consolidation of the Correctional Institutions in: Dubrava, Gjilan, Lipjan, Peja, Mitrovica and later on all other detention centers in Kosovo.

Kosovo Correctional Service under the international monitoring, along with the improvement of the building

\footnotetext{
${ }^{1}$ The United Nations Interim Administration Mission in Kosovo or UNMIK was established pursuant to Security Council Resolution 1244.

2 The Special Representative of the Secretary-General ('SRSG') is the head of UNMIK.
} 
infrastructure has recruited continuously local staff to fulfill its needs to be operational. During this process the Kosovo Correctional Service has faced many different challenges, including the working sub-cultural aspects of the Detention Centers and the Correctional Centers (Kauffman, 1998).

Kosovo Correctional Service has been established based in the international criteria's and standards, similarly to the most advanced correctional systems in Europe thanks to the most advanced practices brought by the international staff from their countries. The priority of the Kosovo Institutions was to ensure that there is enough space to hold all the prisoners as well the detained persons. For a certain period these institutions were not prepared to deal with protected witness prisoners due to the lack of the legal infrastructure ${ }^{3}$ as well the buildings to settle this specific category of the prisoners. Additionally, during this period of time there was no High Security Prison. Instead there was a modified building where the high risk prisoners were settled and as result there were three escapes from this institution.

\section{Security and treatment of the protected witness prisoners during administration by Ministry of Justice, Government of Kosovo on 2008 - 2013}

The transfer of the competencies from UNMIK to the Kosovo Government ${ }^{4}$ in June of 2005 was done in accordance with the UNNIK Regulation 2005/53, which has set the legal bases for the establishment of the Ministry of Justice. The Regulation had foreseen the initial competencies of the Ministry of Justice which started to function in March 2006. After this phase, the Kosovo Correctional Service has started with the recruitment of the new management composed of local staff under the monitoring of the Kosovo Ministry of Justice and operating independently from UNMIK. This phase of transferring competencies was continuous until the declaration of Independence by Kosovo in year 2008 and it had a specific importance in continuation of professional development of the correctional institutions (Dreshaj, 2010). During this period of time, many weaknesses were noticed into managing the high risk prisoners and the protected witness prisoners. Kosovo had no High Security Prison and no Witness Protection Prison, which situation created many difficulties in managing this specific category of prisoners. The prison for the protected witnesses was established in 2009 and it has become operational in 2011. In 2012 the work to build the new High Risk Prison has commenced. This prison is expected to become operational during October 2013.

By building the prison for the sentenced protected witnesses, the conditions have been created to settle this specific category into adequate institution where the level of security and their treatment is in accordance to the their needs, and in accordance to the relevant laws and international requirements for this specific category.

The Witness Protection Unit became operational in July 2011. Since the beginning of October 2011, first protected witness prisoners have been settled in. Their settlement, holding and the security has attracted a lot of media attention, general public and from other local and international factors. This situation has made this institution of great importance to mobilize all its capacities and to increase the level of security, to increase the level of professional performance by its staff, to build modern technology for the technical security of witnesses. Along with the physical security that the prison offers, we will be more professional in realizing our mission in better management of this specific category in prisons. Current situation requires the attention and permanent awareness by its professional staff working in this institution as well by other state institutions. The Ministry of Justice and the Government in general should take more efforts to assist this institution to achieve its main goal, which is "to provide a safe environment and harmless for all the prisoners who are included into witness protection prison program".

The establishment of these conditions for this specific category of prisoners has motivated others to testify for different criminal act despite the fact that they have been participants in committing these criminal acts. This is influencing strongly into the public perception that no case is remaining unsolved and it is increasing the citizen's awareness to report crime in general. Until now we have faced many difficulties and challenges in dealing with this specific category of prisoners, but with the support from the international community in Kosovo - EULEX, Kosovo Police and other law enforcement institutions in Kosovo we have managed relatively well the situation. Through legal provisions (law 04/L-015) and other secondary legal documents, we have defined the means for professional cooperation between the Kosovo

\footnotetext{
3 The UNMIK Regulation 1999/4, represented the applicable legal base for the work of the Correctional Institutions. This Regulation enabled the implementation of the Law on Execution of Penal Sanction from the year 1977. The applicable legislation included also the European prison rules and the international standards. It is important to mention that it there was a need for a specific Law for protected witness prisoners which would define the norms and standards for security and treatment of this specific category from prisoners.

${ }^{4}$ In June 2006, the process of transferring competencies from UNMIK Department of Justice to the Ministry of Justice of the Government of Kosovo, took place.
} 
Correctional Service - Prison for sentenced protected witnesses and the Kosovo Police. The Kosovo Correctional Service is responsible for transporting the protected witness prisoners, while the Kosovo Police is responsible to provide security during such transportation and the security at the institution where the session, the interview or trial is taking place. This cooperation is contributing to avoid problems in securing the protected witness prisoners. Along with the security, the establishment of appropriate conditions such as medical treatments within the institution, quality of food, free activities and visits, all of these have contributed to make the work with this specific category of prisoners safer and better. Currently there is still a need to have the support from the Ministry of Justice as well from other governmental bodies to increase its efficiency on witness protection prison program. This program shows that there is a need for increased financial funding; therefore, in the future there will be large expenditures and a sustainable budget line is required to increase even more the security level for a better treatment of this category of prisoners with the purpose of meeting the international standards. Despite the fact that this program is very expensive for Kosovo it is necessary to provide necessary and sustainable financial funds to ensure the future of this program. Its financial sustainment it is important to contribute the creation of the proper perception by the staff and others, in supporting the safety and security of this category of prisoners as well as the overall security in Kosovo. All the indications show that the number of prisoners to enter this program will increase in the coming months and years, which shows the necessity for the urgent budget review and the increase of human resources.

\section{Challenges and problems during the work with protected witness prisoners}

Working with, and managing this specific category of prisoners is facing different challenges and problems ${ }^{5}$ which requires a more professional approach and a permanent support from other governmental bodies.

We are lacking 6 :

- The best international practices regarding the treatment and security for this specific category of prisoners;

- Harmonized standards within the witness protection system;

- A fully operational Witness Protection Unit;

- Insufficient financial support for a quality work on the program;

- Specialized equipments;

- Advanced training for the staff to manage this specific category.

The witness protection program is the responsibility of the state institutions, but it is necessary to have a regional approach and cooperation in order to exchange best practices and to ensure the financial autonomy of these witness protection units.

During last two years the program we have faced also the attempts of outside groups to eliminate or abduct two different attempts from different criminal groups to eliminate or abduct the witnesses while being transported from one location to another. In both cases the Witness Protection Unit has hardly achieved to secure the witnesses and to prevent their abduction by these criminal groups. We managed to prevent this thanks to the intervention of the Kosovo Police Special Units, who successfully reacted in the right moment.

Despite these experiences, it is obvious that such attempts will occur in the future as well. Therefore, it is necessary to properly train the staff, to adopt the best international practices from experienced international units for this unit and to build the necessary legal infrastructure including the secondary legal acts which would cover every element of the work of the Witness Protection Unit.

\section{Conclusion}

Providing necessary and regular budget as well providing additional financial funds for staff that works overtime or does additional work it is vital for better functionality and management of the Witness Protection Unit. Additionally, it is important to plan for an emergent financial fund to cover any unexpected expenses of this institution to ensure its operational needs are covered as well including the costs originating from additional security measures and increasing number of needs for transportation and escort. The organizational structure and number of human resources for the Witness Protection Prison have been determined, depending on the position in which they operate within the prison.

\footnotetext{
${ }^{5}$ A statement from the author in the capacity of the Commissioner for Kosovo Correctional Service.
}

${ }^{6}$ Ibid. 
Currently a total of 53 of personnel are assigned to cover all shifts $24 / 7$ including the days off during holidays. The need to increase the number of personnel has emerged in order to cover the duties of witness transportation which would result with additional financial costs. The overall conclusion is that due to the nature of this work there is a need not only to increase the human resources but also to provide advanced transport vehicles which would comply with the necessary technical and security needs.

Furthermore, for successful performance of the personnel engaged in witness protection it is necessary to provide the necessary training. Currently the personnel is trained in basic level of operation but the needs for more advance trainings in fields of driving/ transportation, health, and other treatment programs have become imminent. To make sure that the treatment of protected witness prisoners is in accordance with the highest standards it is required to have available the additional medical personnel to ensure medical needs of this specific category of prisoners. The monitoring system of cameras, the signalization system and the alarm system have been proven to be in good working condition in last two years since their installation.

Despite a professional and close cooperation between the Witness Protection Prison and other law enforcement and justice institutions, there is still a need to improve this cooperation in higher levels such as information and intelligence sharing in order to provide a better security for the protected witness prisoners. This information and intelligence sharing process would be beneficial to conduct a risk assessment and to take in consideration all necessary options in emergency cases such as evacuation of witnesses.

It is a continuous goal of the Witness Protection Prison to plan and to ensure that protected witness prisoners have same comparable privileges as other prisoners in other correction institutions.

To ensure that protected witness prisoners have adequate treatment, the Prison has provided for them various rehabilitation and therapeutic programs, various free activities within the prison, as well has the opportunity for work within the institution. Furthermore to ensure their welfare, the institution has provided the opportunity to get visitations and to have recreational, sportive and training activities with the Prison for Witness Protection.

\section{References}

Bajgora, Ali. (2001), Some characteristics of crime and punitive policy in Kosovo, 2001.

Elezi, I.Hysi. V, (2006), Penal Policy, PEGI, Tirana.

Gashi, R. (2001), Execution of prison sanctions in Albania, Prishtina.

Halili, R. (1970), Purpose and reasons of sanctions on murder crimes, Progress-6, Prishtina.

Halili, R. (1970), Execution of penal sanctions to the juveniles, Progress-10, Prishtina.

Halili, R. (1973), Penal sanctions as public protection measures, Progress-9, Prishtina.

Halili, R. (1985),:Penal Sanctions according to the Customary Law in Kosovo, Entity for educational texts and tools in SAP of Kosovo, Prishtina.

Omari, L. (2002), Rule of Law, Academy of Science of Albania, Publisher LILO, Tirana, 2002.

Zaganjori, Xh. (2002), Democracy and Rule of Law, Publisher Laurasi, Tirana, 2002.

Ramadan, M. (2003), Penology and the system of execution of criminal sanctions, Novi Sad-Beograd, 2003.

Sahiti, E, (2005), The Law of Penal Procedure, University of Prishtina, Prishtina.

Salihi, I, (2003), The Penal Law, University of Prishtina, Prishtina.

Salihi, I, (2005), The Penal Law for the Juveniles, University of Prishtina.

Clinton, Bill, (2004), My life, Knopf Doubleday Publishing Group, Washington.

Dreshaj, Arben, (2010), The role and importance of correctional institutions in the socialization of convicted persons Litografia, Gjakovë.

Halbauer, Volker, (2012), Kosovo Force, Key Facts and Figures, Bruxel.

Kauffman, Kelsey, (1998), Prison officers and their world, Harward University Press, London.

Law nr. 04/L-015, Law on Witness Protection, pursuant to Article 65 (1) of the Constitution of the Republic of Kosovo. Adopted by the Assembly of Kosovo on 29 July 2011. Promulgated Decree of the President of the Republic of Kosovo on 12 August 2011, Article 5 para. 1-3 and Article 14.

Official web page of Ministry of Justice of the Republic of Kosovo, (online) Available: http://www.md-ks.org/?page=1,62

Sadiku, Isuf, (2010), The execution of criminal sanctions in light of the new international acts, Papirus Print, Gjilan. 